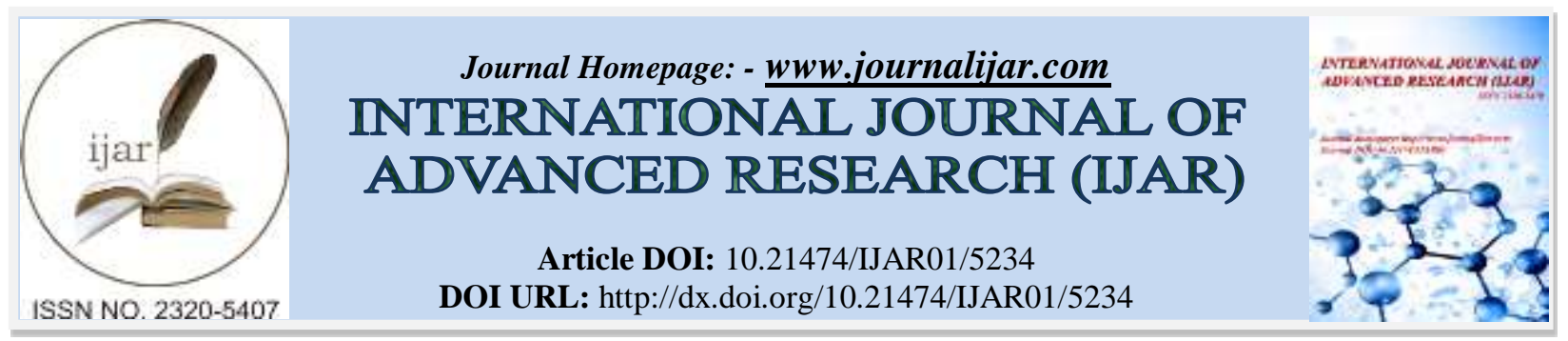

RESEARCH ARTICLE

\title{
BRIEF REVIEW ON PROPHYLAXIS AND TREATMENT OF CARIES DISEASE.
}

\section{Nilviane Pereira Dias ${ }^{1}$, Thaysa Moreira Vasconcelos ${ }^{1}$, Lorena Trivilin Menezes ${ }^{1}$, Leandro Moreira Tempest $^{1,2}$, Idiberto José Zotarelli Filho ${ }^{2}$ and Simone Andreia Gubolin ${ }^{1,2}$.}

1. University Center North Paulista (Unorp) - São José do Rio Preto - SP, Brazil.

2. Post graduate and continuing education (Unipos), Street Ipiranga, 3460, São José do Rio Preto SP, Brazil 15020-040.

\section{Manuscript Info}

Manuscript History

Received: 21 June 2017

Final Accepted: 23 July 2017

Published: August 2017

Key words:-

Caries disease, Oral diseases,

Treatments.

\begin{abstract}
Introduction: It begins in the enamel of the tooth, in the outer surface and hard of the tooth. Its surface, perfectly smooth, becomes increasingly porous. At this stage, if we discover the problem, everything is still reversible. Dental caries are holes that are caused by the decomposition generated by the action of the bacteria in the mouth. The interior is soft and contains nerves and blood vessels. Cavities are produced when the decay crosses the enamel and reaches the inner cavity of the tooth. Extreme pain is felt when decomposition reaches the nerve. Cavities are not harmful when treated correctly. Objective: The present study aimed to make a brief literary review on caries disease and how to prophylaxis and treatment. Methods: Experimental and clinical studies were included (case reports, retrospective, prospective and randomized trials) with qualitative and / or quantitative analysis. The words were included "Caries disease", "Oral diseases", "Treatments". The total of 35 articles were found involving caries disease. A total of 25 articles were evaluated in full, and 21 were included and discussed in this study. Conclusion: The more advanced the case of caries, the more complex the procedure. Therefore, the sooner a clinical intervention in the advancement of the caries, the easier, the less painful and cheaper will be the solution of the patient's problem.
\end{abstract}

Copy Right, IJAR, 2017,. All rights reserved.

\section{Introduction:-}

According to the World Dental Federation (FDI) hypothesized that over $95.0 \%$ of the world population will have some oral disease in your life. Further, only $64.0 \%$ of the population has access to oral hygiene. Furthermore, in the United States the prevalence of caries is very low [1]. It begins with the tooth enamel, the outermost and hard surface of the tooth. Its surface, perfectly smooth, becomes increasingly porous. At this stage, if we discover the problem, everything is still reversible [1-3].

Dental cavities are orifices that are caused by the decomposition generated by the action of the bacteria in the mouth [4-6]. The inside is soft and contains nerves and blood vessels. Cavities are produced when the decay crosses the enamel and reaches the inner cavity of the tooth. Extreme pain is felt when decomposition reaches the nerve. 
Cavities are not harmful when treated correctly. Leaking a hole in the tooth and exposed nerve can lead to infection and even tooth loss. An untreated infection will invariably reach the root and the bone, causing an abscess [7-9].

The present study aimed to make a brief literary review on caries disease and how to do prophylaxis and treatment [10]. Thus, the rapid growth of the biofilm that favors its energetic metabolic activity is justified by the feeding of the bacteria through the sugars ingested in the diet, where acidification occurs from the fermentation process of the carbohydrates, intermediated by microorganisms such as Streptococcus mutans, Lactobacillus acidophilus, S. salivarius, Eubacterium, Propionibacterium, Actynomycesisraelli, which are responsible for the demineralization of tooth tissues [11].

The present study aimed to make a brief literary review on caries disease and how to do prophylaxis and treatment.

\section{Methods:-}

Experimental and clinical studies were included (case reports, retrospective, prospective and randomized trials) with qualitative and / or quantitative analysis. Initially, the key words were determined by searching the DeCS tool (Descriptors in PubMed, Health Sciences, BIREME base) and later verified and validated by MeSh system (Medical Subject Headings, the US National Library of Medicine) in order to achieve consistent search.

\section{Mesh Terms:-}

The words were included "Caries disease", "Oral diseases", "Treatments". The literature search was conducted through online databases: Pubmed, Periodicos.com and Google Scholar. It was stipulated deadline, and the related search covering all available literature on virtual libraries.

\section{Series of Articles And Eligibility:-}

A total of 35 articles were found involving caries disease. Initially, it was held the exclusion existing title and duplications in accordance with the interest described this work. After this process, the summaries were evaluated and a new exclusion was held. A total of 25 articles were evaluated in full, and 21 were included and discussed in this study.

\section{Literature Review:-}

The oral microbiota is the most complex of all our body, there are over 30 different genres, covering more than 500 different species, the authors showed that, in the mouth, there are close to 350 species bacterial been developed and 200 were distinguished by genetic studies [11-13]. Being dental caries a multifactorial disease is essential the presence of microorganisms for their development. The main evidenced etiologic agents are the species Streptococcus mutans and Streptococcus sobrinus [14].

Caries was only a condition in adults and only appeared in areas of scars and fissures, present in premolars and molars, but with the beginning of industrialization, high sugar production, caries becomes visible in children and In teeth of smooth surfaces, bringing a concern to dentistry [15]. The multifactorial etiology of caries appears in the combination of factors such as diet, microbial flora of the mouth, salivary $\mathrm{pH}$, oral hygiene, fluoride deposition, tooth susceptibility, socioeconomic level, among other characteristics that express the individual's lifestyle [16].

Tooth decay is caused by the action of an acid (which comes from the decomposition of food and drink produced by the action of the bacteria that inhabit the mouth), which causes the erosion of the enamel and its subsequent corrosion [17]. The main bacterium responsible for caries is Streptococcus mutans. Other factors that trigger dental caries are poor oral hygiene, frequent ingestion of sugary foods, etc. The main symptoms of caries are acute pain, inflammation, increased sensitivity to food or cold or hot drinks, bad breath and tooth loss [18].

There is a variety of methods for detecting caries that will lead to the choice of appropriate treatment for each type of injury [14]. Among the factors that lead to the choice of the diagnostic method is the morphology of the tooth, where the surfaces of scars and fissures require special care because they present delicate areas that require more attention [19]. The most common diagnostic methods are: conventional radiography, fiber-optic transillumination, visual inspection, tactile inspection and laser fluorescence [20].

The best care you can have for your teeth is prevention, for this you need to: make sure that the community's drinking water has been fluoridated at a level of one million to one million; Use toothpaste; brushing teeth and 
flossing; regularly visit the dentist to do the cleaning of the dental arches; have a balanced diet; avoid sweets and sugary drinks between meals; saliva helps to prevent cavities as long as the mouth is clean [21].

The prevention of caries disease has as main objective to prevent the appearance of incipient lesions and not simply to restrict the damages of the disease [15]. One of the main and most common challenges in oral health is the control of dental plaque and consequently the control of dental caries and gingival inflammation, mechanical methods such as the use of toothbrushes and dental floss when applied efficiently. They can promote a correct plaque Control [11]. Health professionals have a responsibility to act in the prevention of diseases, minimizing risks and promoting favorable conditions so that it is possible to achieve and maintain oral health. On the other hand, patients also need to be aware of their role in health care [21]. The prevention of dental caries is possible through regular oral hygiene [21].

One of the main factors related to dental caries is directly related to the biofilm, a film acquire that soon originates when the oral hygiene is made, with the formation of this layer, pathogenic bacteria from the food and that is not excluded with a good oral Hygiene uses Of this layer that would be a kind of "protection" as a shelter. The dental biofilm thus formed is composed of a heterogeneous group of microorganisms in the different sites and tends to stabilize with the passage of time. These biological communities are embedded in polymer matrices [8]. Authors have demonstrated the relationships between the biofilm and the multiple biological determinants that influence the possibility of caries lesion development. The teeth are colonized by bacteria that exist in the biofilm, whose metabolism causes fluctuations in $\mathrm{pH}[19,20]$.

Thus, the control of the presence of microorganisms in the oral cavity influencing the caries process, or being influenced by organic salivary, immunological and chemotherapeutic factors, should not be considered for the establishment of prevention strategies, and the simple presence of microorganisms in the oral Cavity, whether in saliva or plaque, is not a factor that determines the onset of disease caries [17-20].

\section{Conclusion:-}

The more advanced the caries case, the more complex the procedure. Therefore, the sooner a clinical intervention in the advancement of the caries, the easier, the less painful and cheaper will be the solution of the patient's problem.

\section{Competing interests:-}

The authors declare no competing interests.

\section{References:-}

1. Zárate, Cibele Bonfim de Rezende. influência da concentração de sacarose da dieta e do acesso ao fluoreto na prevalência de cárie dentária. 2012. 86 f. Tese (Doutorado) - Curso de Nutrição, Universidade Federal do Mato Grosso do Sul, Campo Grande, 2012.

2. Rosa, Cíntia Vieira da. Cárie precoce na infância: a importância do cuidado de enfermagem. 2012.55 f. Tese (Doutorado) - Curso de Enfermagem, Universidade Federal do Rio Grande do Sul, Porto Alegre, 2012.

3. Souza, Dalva Inês de et al. Manual de orientações para projetos de pesquisa. Fundação Escola Técnica Liberato Salzano Vieira da Cunha, Nova Hamburgo, v. 4, n. 1, p.1-55, 2013.

4. Melo, Marcia Maria Dantas Cabral de et al. Fatores associados à cárie dentária em pré- escolares do Recife, Pernambuco, Brasil. Caderno de Saúde Pública, Rio de Janeiro, v. 27, n. 3, p.471-485, mar. 2011.

5. Soraggi, Maria Bernadete Soares et al. A cárie dentária e suas condicionantes em crianças de uma escola pública municipal em Niterói - RJ. Pesquisa Brasileira em Odontopediatria e Clinica Integrada, João Pessoa, v. 2, n. 7, p.119-124, ago. 2007.

6. Oliveira, Maxwell Ferreira de. Metodologia científica: um manual para a realização de pesquisas em administração. Universidade Federal de Góias, Catalão, v. 4, n. 1, p.1-72, mar. 2011.

7. Aguiar, Tatiana Carolina de et al. Avaliação do perfil de risco de cárie dentária em gestantes de Araraquara, Brasil. Revista Cubana de Estomatologia, Ciudad de La Habana, v. 48, n. 4, p.1-8, out. 2011.

8. Gerhardt, Tatiana Engel; Silveira, Denise Tolfo. Métodos de Pesquisa. Universidade Federal do Rio Grande do Sul,Porto Alegre, v. 1, p.1-121, fev. 2009.

9. Ministry of Health Department of Health Care / Secretariat of Health Surveillance Department of Primary Care General Coordination of Oral Health. Project SB Brazil 2010: National Oral Health Survey - Main Results. Brasilia in 2011. 
10. Mamai-Homata E, Topitsoglou V, Oulis C, Margaritis V, Polychronopoulou A (2012). Risk indicators of coronal and root caries in Greek middle aged adults and senior citizens. BMC Public Health. 12:484.

11. Colombo AV; Barbosa GM; Higashi D; di Micheli G; Rodrigues PH; Simionato MR (2013). Quantitative detection of Staphylococcus aureus, Enterococcus faecalis and Pseudomonas aeruginosa in human oral epithelial cells from subjects with periodontitis and periodontal health. J Med Microbiol; 62 (Pt 10): 1592-600, Oct. ID: mdl-23800598.

12. Almståhl A; Kareem KL; Carlén A; Wårdh I; Lingström P; Wikström M (2012). A prospective study on oral microbial flora and related variables in dentate dependent elderly residents. Gerodontology; 29(2): e1011-8, Jun. ID: mdl-22122551.

13. Patel, Reena (2012). The State of Oral Health in Europe. Report Commissioned by the Platformfor Better Oral Health in Europe.

14. Jackson SL, Vann WF, Jr, Kotch JB, Pahel BT, Lee JY (2011). Impact of poor oral health on children's school attendance and performance. Am J Public Health;101:1900-6.

15. Phipps KR, Ricks TL, Manz MC, Blahut P (2012). Prevalence and severity of dental caries among American Indian and Alaska Native preschool children. J Public Health Dent.;72:208-15.

16. Eigbobo JO, Umanah AU (2013). Perception of graduating medical students on child and maternal oral health in a selected tertiary institution in the southern part of Nigeria. Nig Q J Hosp Med. Apr-Jun; 23 (2) : 99-104.

17. Broughton JR, Person M, Maipi JT, Cooper-Te KR, Smith-Wilkinson A, Tiakiwai S, Kilgour J, Berryman K, Morgaine KC, Jamieson LM, Lawrence HP, Thomson WM. (2014). Ukaipō niho: the place of nurturing for oral health. N Z Dent J. Mar;110 (1) : 18-23.

18. Donald L. Chi (2013). Reducing Alaska Native paediatric oral health disparities: a systematic review of oral health interventions and a case study on multilevel strategies to reduce sugar-sweetened beverage intake. Int $\mathbf{J}$ Circumpolar Health. 72: 10.3402/ijch.v72i0.21066.

19. Delemotte M, Valcarcel J, Tramini P (2013). Oral health and precariousness in pregnant women. Odontostomatol Trop. Mar;36 (141) : 14-26.

20. Pentapati KC, Acharya S, Bhat M, Rao SK, Singh S (2013). Knowledge of dental decay and associated factors among pregnant women: a study from rural India. Oral Health Prev Dent.11 (2):161-8. doi: 10.3290/j.ohpd.a29734.

21. Vergnes J-N, Kaminski M, Lelong N, Musset A-M, Sixou M (2012). Frequency and Risk Indicators of Tooth Decay among Pregnant Women in France: A Cross-Sectional Analysis. PLoS ONE 7(5): e33296. doi:10.1371/journal.pone.0033296. 